\title{
Raquel Osborne
}

Universidad Nacional de Educación a Distancia (UNED), Spain

\begin{abstract}
This is a story about 'good girls' and 'bad girls' - the political prisoners and the nonpolitical prisoners of the first period of Franco's regime. The political prisoners, mostly communists, differentiated themselves from non-political prisoners by refusing to have anything to do with the non-normative sexuality - auto-eroticism and lesbianism - that was rife among the non-political prisoners, many of whom were prostitutes. Taking a unique stance, the sexual liberalness of the political prisoner, Carlota O'Neill, set her account apart from the rest of the written testimonies that have been analysed. This article examines the reasons for these diverging views on sexuality. Along with testimonies, this work of historical memory is based on historical studies and interviews.
\end{abstract}

\section{Keywords}

Francoism, non-political prisoners, Carlota O’Neill, political prisoners, sexuality

\section{Introduction}

During the 1980s, there was a widely known debate within Anglo-Saxon feminist circles on female sexuality, on 'good' and 'bad' girls in terms of sexuality. The underlying dispute was whether or not feminism should take a stance on a supposed correctness concerning female sexuality. The discussions focused around issues such as pornography and prostitution (Echols, 1989; Osborne, 2002 [1993]; Snitow et al., 1983; Vance, 1984; Walkowitz, 1983). In Spain, we are analysing a similar issue between the 'good' and 'bad' girls during Franco's first years in power. Female political prisoners and non-political prisoners, many of them prostitutes, are the key figures in this debate.

\section{Corresponding author:}

Raquel Osborne, UNED, Facultad de CC. Políticas y Sociología, Departamento de Sociología III, C/ Obispo Trejo s/n, 28040, Madrid, Spain

Email: rosborne@poli.uned.es 
Franco's regime imposed heavy political repression in the impoverished Spain of the 1940s and 1950s. The regime packed the penitentiaries full of female political prisoners, who were never recognized as such, as well as female non-political prisoners. The prisoners were subject to prevailing poverty and the harsh conditions of confinement. The need for physical as well as political survival forced the political prisoners into a firm political organization, which included a radical negation of sexuality, whether it be one's own or that of others. In contrast, the non-political prisoners, who were mainly less-educated women and serving shorter sentences, would indulge in acts of autoeroticism and lesbian practices. Their sexuality could be traded for favours and, in addition, the guards used sex as a means of blackmailing them. As a result, the political prisoners abhorred these expressions like the plague beyond the fact that they shared the puritan mentality of the working class in which they were brought up (Osborne, 2009).

Francoism, like any regime that wants to dominate every aspect of social life, operated on various levels: repression, with the great issues of the war and misery that followed the post-war era, the Catholic morality, the social control and public censure. Prison, hunger, exile and death were totally against freedom and sex. But the regime did more than punish and repress. As with any dictatorship, its goals were not fully realized even if it marked the lives and experiences of several generations of Spaniards. There was a resistance, not just political, but also class, territorial, personal and sexual.

Such was the case of Carlota O'Neill, a political prisoner during Franco's regime, whose liberal bent, social background, and career as a writer seemed to have contributed to her tolerance to sexuality and sympathy to non-political prisoners. O'Neill never felt the need to keep a social distance or to make her sexuality a barrier to non-political prisoners - most of them prostitutes - about whom she writes quite dispassionately and without any hint of sanctimony.

In this article, we shall further investigate the reasons behind the different points of view on sexuality among the female political prisoners. In an attempt to explain these divergent standpoints, we will look at an array of factors, such as education, social background, and political activism.

The analysis of this subject furthermore allows us to exercise the historical memory of female sexuality, which in general has been silenced and denied. In particular, we look at those non-normative practices such as 'free love', prostitution, and lesbianism. The main sources for our research come from the work of historians on the characteristics of female repression of that time, in general and, specifically, in prisons (Hernández Holgado, 2003; Moga, 2004; Sánchez, 2009; Vinyes, 2004; Vinyes et al., 2003). These sources are combined with the testimonies of political prisoners since the 1960s (Cuevas Gutiérrez, 2004 [1985]; Doña, 1978; García, 1982; O’Neill, 2006 [1964, 1978]). To analyse the figure of Carlota O'Neill, we will discuss her writings on her way through the prison in Melilla - a Spanish city in the north of Africa - (O'Neill, 2006). They are relevant to refer to the context of that period and to the prison experience. This will help us to get familiar with the character and her thinking. We will also use data and documents from our 
different encounters and telephone conversations with her daughter, Carlota Leret O'Neill, ${ }^{1}$ who is the principal custodian of her parents' memory, Virgilio Leret and Carlota O'Neill.

These testimonies have compelled us to highlight what most other readings have kept in the dark, namely, the aspects of sexuality that represented a barrier between most of the political prisoners and many of the non-political ones, between the 'good girls' and the 'bad girls'. Despite the proliferation of testimonies and essays on women's repression under Franco's dictatorship, even today sexuality is not given the attention it deserves. Frequently, as we know, sexuality is overlooked in research, since it is deemed as unimportant. This fact is combined with the difficulty of conducting research on sex matters. This is doubly true in the case of female sexuality, since it is often believed to be practically non-existent. The significance of this work is in bringing extant information to the forefront. Much of this information was made public years ago, but nobody took the slightest note.

\section{The prisoners of Franco: Women 'without morals and shame'}

According to official documents dating back to 1952, in Spain there were 25,813 male prisoners and 2864 female ones, classified under the following categories: 'Marxist rebels', 'non-common-law crimes after April 1st 1939' and 'commonlaw crimes' (Cuevas, 1953: 16). In another important document of that time, it is noteworthy that there were 716 female prisoners segregated under the distinct category of 'women of ill repute' (Comission Internationale contre le Régime Concentrationnaire, 1953: 205). ${ }^{2}$ According to the documents from the military trials of the Franco's regime, the only profession that was separated from the category 'housewife' was 'prostitution' (Sánchez, 2009: 65-66).

What is most clear -says Hernández Holgado- is that, officially, female political prisoners were never recognized as such. This was the hallmark of female incarceration: the idea of women in prison under the mixed criteria of politics and morality. In Cárceles españolas [Spanish prisons], for instance, terms such as delinquent and deviant women are used as from 1931, with a net increase of female prisoners as a result of the Civil War. The emphasis is placed on moral correctness (as in the entire history of female penalization, ever since the first women's prisons were established). Under this category, all female prisoners were treated the same way, whatever the crime committed (Cárceles Españolas, 1948: 71-72). Thus, women were not only indicted as rojas ['reds' in the feminine] - rojos ['reds' in masculine] was the term applied to the Republicans during the Spanish Civil War (1931-1936) by Franco's supporters - but because they were also seen as unnatural women, who had corrupted their men and Spain as a whole. The rojas were not, by definition, 'decent people'. Rather, they were women 'without morals and shame' (O’Neill, 2006: 133).

Women and men were subjected to repression partly in the same manner: trials, prison sentences, executions and purgings. However, unlike men, women were not 
doomed to annihilation, but to selective repression, as a deterrent (Sánchez, 2009: 45 and 64). Women were seen as the cause or the symbol of the destruction of Spain, and therefore were to be repressed differently. The root cause was the transgression of their traditional female role under the Second Republic (1931-1936).

It is well known that Francoism intended to use as its foundation the denial and the reversal of the ideals of the Republic. The new regime established itself during the Civil War. When the war was over and the dictatorship settled in, it claimed that the degradation responsible for bringing about the clash between Spaniards was a consequence of the abyss to which the country had sunk during the Republican period.

Central to such a negative vision of the 'New Spain' upheld by the Franco dictatorship was the change of status of women fostered during the Second Republic through the implementation of gender equality measures, such as the right to vote, divorce and abortion, among others. However, the social and cultural changes were clearly under way.

In the heat of the generation of 1927 and the social and cultural effervescence of that time, some young women, either for academic or professional reasons, or because of their family background, gained access to new relationship spaces. Educated, driven and determined bourgeois young women deviated from the acceptable paths for women in their social environment - courtship, marriage, children and home life - to seek new horizons where they could be fulfilled as rational beings (Mangini, 2001: 31). They were 'new women' who rejected the role of 'domestic angels' and tried to enter the masculine spheres of work, culture and knowledge.

The hopes that the Republic ushered in and the new opportunities for women made it possible for them to become fully-fledged citizens and access those spheres, which had been previously out of bounds. Therefore, to Franco's regime, alongside punishment, the best way of regenerating Spain, was to impose a very rigid role of femininity. To this end, different forms of repression were applied to men and women.

Carlota O'Neill echoed this idea of targeted repression, which was particularly violent towards educated women, who were seen as transgressors par excellence of the traditional female role (O'Neill, 2006: 121):

The girls who were caught ... belonged mostly to youth workers' unions; they knew how to read and about their rights. The Falangists went out to track them down at night... They would capture and rape them in the fields; they would prey upon them, one after the other, like dogs. Some young women died in the struggle, others were killed, some went to prison; their fate was a matter of chance. (O'Neill, 2006: 67-68)

As has always been the case in the history of warfare, women were perceived as a piece of territory through which men expressed their dominion, demonstrating in a single gesture both their victory as conquerors and the subjugation of the 
vanquished. Killing these women was sometimes not enough, they also had to be humiliated and exposed to public shame (Sánchez, 2009: 218-219) in two particular ways: one by cutting off all of their hair, a quintessential symbol of femininity:

That young woman's haircut made a mockery of her; it was shaved, like a man's, adorned with ridiculous tufts, as if they were stiff little horns. The Falangists surrounded her with laughter and lewd words, and each of them would take turns chopping away at her hair with the scissors, disfiguring her. (O’Neill, 2006: 92)

Another typical way of humiliating women through the use of their bodies was with 'la purga de ricino' [purge of castor oil]. Although this practice was carried out largely against women, it was also used against men. Pura Sánchez recounts this harrowing story of July 1936:

To this woman ... before killing her, they gave her a laxative of castor oil. This was the norm in the whole of liberated Spain. They gave a laxative of castor oil to their prisoners and whether they were later killed or not, at least they were made to rid the body of bad leftist ideas. But with this woman, they did not stop there. She drank a whole litre of the repulsive oil, and was mounted on a donkey and paraded through the village, until the donkey's body was shining with the excrement coming from the unfortunate woman. A local band was playing festive music to accompany this infamous procession. (Sánchez, 2009: 218)

A classic form of submission was the clear indication that women were nothing more than a sexual object for men, and if they did not consent, they could lose their freedom, as a bare minimum:

... she had that encounter on a bus: a fat, red faced man, with thick lips and a big nose; a man who presumes that he can have sex with any French woman he meets. Germaine did not want to spend the night with him; she had to spend many nights with us in prison. (O’Neill, 2006: 89)

The Catholic Church played a fundamental role in this crusade to restore the 'dignity' of women that had been lost during the time of the Republic. The Church was extremely concerned about female sexual morality and the threat that it posed towards traditional family life.

In the new state, the restoration of the traditional family structure became a symbol of this new morality. Being a 'wife and mother' became the only role assigned to the new woman, this role adorned with the virtues necessary to embody the ideal of 'the motherland'. Official morality would be guided by the notion of steering all women towards this goal: From Empire to God, through the mother country, were slogans of the new regime. The dominance of the Church at every level of political, social and family life, due to its unconditional support for Francoist ideology, would eventually be known as 'National Catholicism' 
[nacionalcatolicismo]. The re-Christianization of the home and the morality of society were key pillars of the new state:

\begin{abstract}
Very early on the civilian governments organised grandiose 'morality campaigns' that all other institutions served. Since women were the core of social morality, a specific institution was created, namely the Foundation for the Protection of Women, which consisted of Provincial Boards, chaired by Civil Governors. These foundations extended throughout the Spanish territory by 1942. (Nicolás Marín and López García, 1986: 377)
\end{abstract}

The campaigns to monitor and uphold morals included those against concubinage, which was a widespread practice in rural areas (Nicolás Marín and López García, 1986: 381, 372). Bear in mind, that above and beyond a woman's professional activities, she would only have to have lived out of wedlock with a man to be considered 'a woman of ill repute and infamy'. Pura Sánchez mentions the case of a midwife, who was a political prisoner and had lived with her male partner for 20 years out of wedlock (Sánchez, 2009: 69). The aforementioned need of the political prisoners to differentiate themselves from the non-political prisoners, who were mostly prostitutes, was a result of their claim of being considered political prisoners, which was always denied to them. In addition, they were still influenced by the social moral ideas of the time that used the whore stigma (Pheterson, 1996) to disparage other women: 'Here in the neighbourhood, my father in law and brother in law made me look like a whore widow' (emphasis added). These are the words of Soledad Real, a communist political prisoner who, prior to being in prison, had lived with her significant other out of wedlock. They had not registered their matrimonial union in a civil or religious way, as it was often the manner of the working class during the Second Republic and the Civil War, in keeping with the new progressive ideas (García, 1982: 200-201).

Once imprisoned, Soledad Real was accused of having received 'overtures of an immoral nature' through her boyfriend's letters. Real felt the need to defend her own honour in front of one of the prison guards, a devoutly Catholic lady, yet, at the same time, a very good person, because she cared about this woman's opinion and that 'she wouldn't think we are depraved': this is love and not just sex which they are expressing in these letters, explains Soledad Real (García, 1982: 180). She was not a floozy.

\title{
The paradoxes of eugenics: The degeneration of prostitutes and rojas
}

Soledad Real notices the conditions in which lesbianism often developed in the prisons. Not only did lesbianism take place between the non-political prisoners, which could be used by the prison authorities to blackmail them, but some women 
officers used their position of authority to 'hook up with' prisoners:

... and that was the first time I saw the guards behaving like dykes; they were hitting on the young girls, as if they were rapists. The girls could not fight back; the guards had the upper hand. (García, 1982: 178-179)

This leads Real to making the careless assumption that 'one has to be around many prisons to realize that homosexualism ${ }^{3}$ in prison rarely goes hand in hand with personal kindness' (García, 1982: 153), to which she adds:

I have witnessed, at least in prison, that this led to tuberculosis, awful anaemia conditions, and mental disorders. I do not know if this is in any way linked to a lack of nourishment, but the physical decay was very rapid (García, 1982: 147).

The idea of decay and degeneration is used here, consciously or unconsciously, as a way of keeping her distance from the lesbian practices of other prisoners and also as a way of guarding herself against such fickleness. The fact that political prisoners themselves used arguments concerning the degeneration of the race, linked to the social cleansing eugenic approaches in vogue since the 1920s and 1930s, shows how the theme had penetrated into the social body.

This ideology, which was taken to their utmost extreme by the fascist and Nazi regimes in order to eliminate a targeted enemy, is associated in Spain with a Nazi sympathizing psychiatrist called Vallejo Nágera, whom Franco entrusted with the psychiatrization of political dissidents. This doctor believed in the innate inferiority of women, whose social inhibitions created by religion and race were shattered when exposed to Marxist ideologies. It is worthwhile clearing up the following ideas: (1) Franco's regime identified both Marxists and Republicans together as 'Reds' [rojos or rojas], that is to say with political dissidence; (2) in Franco's organicism, Marxism was considered as a virus external to the social body; and (3) when this virus was found in Republican women, they became cruel and violent, much more so than men, and this is because they had overstepped their boundaries of wife and mother. In sum, the rojas were depraved, sick, degenerate and brutal women (Vallejo Nágera and Martínez, 2003: 256-271).

Therefore a strange paradox takes place within Franco's prisons: the political prisoners, in this case, communist women of working-class origin used arguments of degeneration as old as Lombroso himself, to keep social distance from the nonpolitical prisoners. In turn, the latter were horrified at the thought that they would spend their days with women who were degenerates and sinners - the political prisoners. Carlota O'Neill reflects on several occasions the terror of the non-political prisoners, prostitutes in particular, when entering the prison of Melilla and realized that they had to live with political prisoners, such as herself:

Out on the street, people talked about the rojas, of outlaw women, of doomed and loose women; and there we all were, our lacklustre sunken eyes, before them, we were the rojas, these mighty women who had been punished for our sins. (O’Neill, 2006: 78-79) 
And there was also Maimona surrounded by the rojas, as she kept saying in horror. She knew about these men and women, with tails, as if they were apocalyptic beasts, capable of poisoning anyone with their breath, who did not believe in God. Maimona did not want our shadows brushing against hers on the ground, and with furtive glances she kept looking for our horns and tails. (O’Neill, 2006: 81-82)

In other words, prostitutes, the scum of the earth, would go into prison horrified at the thought of being in close proximity with the degenerate rojas. But the 'furtive glances' would soon change, thanks to direct contact and the fair treatment accorded to them by the political prisoners: 'As the days passed, there was always a hand that offered them friendship, a smile of comfort, a word of hope. And eventually, the newcomers, without even realizing it, became sympathetic towards us' (O'Neill, 2006: 78-79); 'Maimona... had long overcome her horror for the rojas; we had no horns or tails, we were women just like her, poor women without a home or a family just as she was, and this shared destiny put her at ease' (2006: 87). The non-political prisoners not only overcame their fears and became good friends with the other women, but also according to O'Neill, 'they became rojas themselves' (2006: 79).

\section{Tradition and modernity in the political prisoners' view of sexuality}

We have already mentioned the different attitudes towards sexuality between Carlota O'Neill and the communist political prisoners. These differences are evident in certain aspects of gender relations and in the manifestation of sexual desire by women, the sensitivity to lesbian relationships and the acceptance or rejection of prostitutes.

Most female prisoners did not suffer as much on account of their husbands' deaths as they did when it came to the deaths of their children. Therefore they did not understand the pain experienced by Carlota when she learned - months after it had taken place - of her husband's execution, Captain Virgilio Leret (O'Neill, 2006: 100). We need to know that the coup d'etat orchestrated by the Spanish fascists on 17 July 1936 found Virgilio Leret commanding Republican aviation troops in Melilla, and Carlota O'Neill and her little daughters vacationing there in a military dredger. Virgilio loyally defended his allegiance to the Republic and was executed at dawn on 18 July, probably the first officer to be killed by Franco's army. Carlota was captured on 23 July and sent to prison, while her daughters were left under the care of a military family, who barely knew Virgilio. This is how Carlota described her first meeting with Virgilio: 'Such lovely ears! his temples!, his hair! The bluest eyes! A tall figure, over 5' 9'” How barbaric! He was so handsome! There was no other man like him. I wanted him for me' (O’Neill, 2006: 296).

After a handsome Moor stayed briefly in the same prison, she describes him as follows: 'Big dark eyes, upright posture, athletic figure, a beautiful eighteen year 
old man' (O’Neill, 2006: 195). Having escaped from prison, 'he was hiding in a brothel in the Moorish quarter, where he had his love, and we, women without love, envied the woman who held him' (2006: 198) (emphasis added).

But where she expresses an overflowing sensuality is in her prison accounts of the adventures of the many cats that swarmed through the cracks of the old walls of the fort turned prison:

\begin{abstract}
'Perico', the head of the big family, lived up to his own sex. He knew he was handsome and roguish, and was the tyrant of his people. Solid, muscular, long-tailed; a constant lust in his eyes, his powerful muscles constantly rippling. He did not beat around the bush, or waste time contemplating lazily like the other cats. His peers knew that they could not challenge him over any female, and so they slunk off quietly into the shadows. Only when he was fed up would he allow frolicking, and sometimes not even then. (O’Neill, 2006: 104)
\end{abstract}

At some point in her writings, Carlota intertwines her story of the cats with that of 'the two women in love... who adopted a two-month-old kitten. They shared their food with it; they always had it on top of their mats, and they would cuddle it as if it was their child, a fruit of their love' (2006: 104).

About these two young women in love, who had been raped by the Falangists, Carlota related:

Out of promiscuity came love. They were two young girls, barely twenty. Scared out of their minds... the clothes torn and dirt-stained by some road, walking hesitantly with blood on their skirts. They met in the Falangists' van ... during raid time. The men had their way with them, ${ }^{4}$ but did not kill them. They were taken to prison. And they went, their hands entwined, huddling closely together like two wounded animals... They comforted, kissed and wiped away each other's tears. At night, they went to sleep in the laundry room. Their love aroused mockery and embarrassment among the honest mothers. (2006: 69-70)

Faced with the usual intolerance of political prisoners towards sexual relations between women, since this was considered personally degrading and a form of blackmailing by the prison staff (Núñez, 2003; Osborne, 2009), Carlota approached the issue with sweetness and delicacy. She concluded that in Ancient Greece, Sappho would have devoted her best verses to them' (O'Neill, 2006: 70). In fact, when she referred to embarrassment on the part of the honest mothers, Carlota was demarcating a position. More recently, Núñez, for example, says that while Carlota differed from the usual stance of the political prisoners, unfortunately she still treated that relationship with scorn although also with a modicum of tolerance (Núñez, 2003: 35). According to her texts, Carlota was not sneering at all. Years later, O'Neill would end up writing a complete volume of literary criticism on Sappho, something very unusual both for the time and place in which it was published - Mexico - even more so for a woman (O’Neill, 1960). 
In this regard, another interesting paradox between lesbianism in jails and the situation on the streets, outside jails, should be highlighted. Regardless of the relatively frequent lesbian episodes told by prisoners, it turns out that sometimes lesbianism was shamelessly tolerated by the prison authorities themselves: "And then it was the dykes who would jokingly ask: Have you seen my husband? Lesbianism occurred right there [in Malaga prison] in the cold light of day' (García, 1982: 153) ' ... the authorities gathered all of them in the so called marriage room (1982: 147).

By contrast, lesbianism was 'absent' in the streets. It was invisible to the official discourse and it seemed completely missing from Spanish women's daily life. The opposite was the case for male 'inversion': Franco's regime did not tolerate the slightest deviance from the most rigid ideal of masculinity embodied by the coupstaging military members and the Falangist bullies. Public repression exerted on male homosexuals and transvestites, deemed not only criminals but also sick people, has left behind a fourfold trace - in police, judiciary, prison and medical terms - as evidence of the (denigratory) recognition of their existence (Arnalte, 2003; Olmeda, 2004).

Going back to O'Neill, where she clearly expresses her ideas on sexuality is when she talks about the prostitutes. Not surprisingly, as the title of Assumpta Roura's book announces, Spain was nothing but 'A Huge Whore House' (2005) [Un Inmenso Prostíbulo]. The impoverished situation of the country turned many young and older women to this trade. Roura also refers to the unceasing attention paid to this issue by the moral authorities, simultaneously tolerating and punishing these 'fallen women', giving rise to a policy with broad Foulcauldian echo.

The bulk of an article (Osborne, 2010) has been devoted to contrasting the views of political prisoners with that of Carlota O'Neill as they relate to prostitution. Here we give you only a taste. As previously mentioned, the regime was keen to identify rojas as degenerates and whores. At that time, and even to this day, there exists a historical division between decent women and whores. Soledad Real provides an example of this mentality. In a transfer of political inmates from one prison to another - these transfers were quite common - they stopped at a city and the lodgings were provided, or course, by the local jail. On the walk from the station to the jail, they had to pass through the main street. Since it was a holiday most of the young men were out. The majority of these men were members of the Falange, and they had an intense animosity towards political prisoners. As the prisoners walked by, the Falangists said 'Look at those prisoners. They must be whores! One of the women heard this and replied: Not whores! Now if you think whores are communists, we are communists!' (García, 1982: 149-150).

As mentioned before, non-political prisoners indulged in certain forms of transgressive sexuality which were unacceptable to the mindset of the militant communist women, whether for themselves or for anyone else. These ideas were very much in tune with the conservative mindset of that time, to which the communist women ascribed. Furthermore, the communists wanted to display exemplary conduct as prisoners. To this, Santiago Carrillo, a former General Secretary of the Spanish 
Communist Party for many years during Franco's dictatorship and a person who was involved in key moments during the Civil War, recently stated:

The problem was not moral... it had to do with self-defense when facing a terribly repressive situation. I can assure that there really was not a repressive stance on sex within the PCE [Spanish Communist Party]. But it is very true that the Spanish labour movement had a very narrow-minded stance on sex. Theirs was a morality not so far removed from that of Catholicism. This took place, and is, frankly, the first time I raise this issue, because the members felt the urge to set an example to society, to be better than all other citizens, to act as role models, as virtuous, pure, immaculate individuals. (Barba, 2009: 117)

In the testimonies of prison life, the communists did not analyse what prostitution was like at the time: there was insufficient communication between the prisoners, and it is clear that the retelling of those experiences was not a priority for the political prisoners. In their writings, they emphasize how the prostitutes behaved in jail, which they found abominable, including indulging in non-standardized sexual practices. This underscores the social distance between the prisoners.

Carlota O'Neill adopts a clearly different position. In her testimony, we can read a dispassionate account of the situations experienced at the time by prostitutes, the ever voiceless. O'Neill deals with them with little sanctimony and real empathy, and lent them her voice (2006: 78 and ss., 178-182, 188-191, 224). Even from the opening lines of her book Una Mujer en la Guerra de España [A woman in the Spanish Civil War], she describes Nador, in the north of Morocco, as 'A picturesque and dirty jumble; there were some cafes, the cabaret and the house of "bad" women, as they are called by kids and by those women who claim they are not bad' (2006 [2003]: 25 emphasis added). She makes clear her disagreement with this label, showing her distance from the label itself, suggesting that 'those women' labellers may be 'bad' as well by means of using a broader sense of the term 'bad'.

Through her pen, we learn something of the abuse suffered by the prostitutes. Although her account does not claim to be exhaustive, it contributes to an emerging mosaic of the reality of prostitution in that historical moment, gathering experiences that would otherwise be lost forever:

In the brothels, military and civilian Falangists unloaded their lust through the torture they inflicted, through the blood they spilled, everything very violent against the prostitutes, who were placed naked in rows and beaten with whips... Binge drinking aroused subhuman instincts; the same gentlemen who the next day would spend hours presiding over war councils, were not seeking in the whorehouses the lustful acts that they would never dare to ask of their wives. They were seeking something more complex and forbidden, which was allowed because none of these women would dare to protest; the threat of being seen as a 'red' was too terrible. Brothel owners ... they laughed gratefully when their patrons only smashed their china, tossed 
furniture through the windows or, in their underwear, bullfighted women. (O'Neill, 2006: 79)

O'Neill denounces the Falangists here not because they sought the services of whores. Her complaint was about the abuse of authority involved in making exploitative demands and committing vile acts with impunity. Alongside the military involved in the coup, the Falangists represented the authority, and could press charges of being rojas against whomever they wanted, not to speak of prostitutes. Paradoxically, both sets of female prisoners faced similar fates.

O'Neill's depiction of prostitution in that period is so accurate that she is quoted as an expert by the leading researchers of prostitution in that particular time (Guereña, 2003: 414; Núñez, 2003: notes 3, 36, 71, 163 and 164). However, these experts did not know that, as early as 1933, Carlota had written a play, that remains unpublished to date, entitled $A l$ Rojo [In The Red], ${ }^{5}$ about the harsh working conditions in a sweatshop, causing young seamstresses to have to resort to prostitution in order to make ends meet.

\section{Reasons for their divergence: Multiple class issues}

Factors such as education, social class and political activism provide some of the reasons that explain the different attitudes of the political prisoners during Franco's time towards non-political prisoners and their sexuality, as well as sexuality in general.

The communist prisoners, working-class women, had put a great deal of effort into taking advantage of educational opportunities opened to them for the first time in history with the modernization of the country brought by the Second Republic. Added to this was the intense politicization and acculturation that emerged with the extensive labour and reformist movements of the time, which enabled them to acquire a new Weltanschaung. In short, they had gained upward class mobility through culture and politics.

At the opposite end of the spectrum were the prostitutes, the result of material and cultural poverty throughout history, aggravated by the war and the right-wing victory. They were relatively uncultured, and coupled with prevailing poverty and the low social status attached to their work, meant that they were seen as the dregs of society. They were involved in many 'bizarre' situations, from which the political prisoners wanted to keep their distance at all costs (Osborne, 2009).

In the case of O'Neill, the fact that she did not express at any moment the need to keep any distance or to erect sexuality as a barrier between the prisoners may have been influenced by certain differences vis-a-vis communist political prisoners.

First, she belonged to an educated liberal and bohemian bourgeois family who was impoverished economically, so that her parents lived in permanent economic disarray (Falcón, 1989: 22-29). In addition, she was forced to work in order to look after her family during periods when her husband Virgilio Leret 
was imprisoned: 'I was a writer ... by lineage. I was going to be one, out of necessity,' wrote Carlota (O'Neill, 2006: 362).

Second, due to the social turmoil, Carlota immersed herself in social and ideological commitments, as did many other writers and intellectuals, during the Second Republic. Her writing addressed women's issues from a leftist point of view: in 1931 she was editor of Nosotras, Revista Femenina [Us Women, Feminine Magazine], a feminist-oriented publication mainly geared to proletarian women. She was interested in 'free love', the right to vote, abortion rights and the living conditions of prostitutes.

Third, O'Neill intensely collaborated in the activities of the Central de Teatro Proletario [Central Proletarian Theatre], which created the theatre group Nosotros, led by César and Irene Falcón. She was involved both as an actress and playwright, in particular with the aforementioned work Al Rojo, which premiered in 1933. These initiatives were in line with the Educational Missions of the Republic, which sought to spread culture to the masses. So did other theatre groups such as La Barraca, organized by Federico García Lorca, and during the time of the Civil War, the Teatro de Acción contra el Fascismo [Theatre of Action against Fascism], promoted by María Teresa León (wife of the well known poet Rafael Alberti). All of them toured extensively throughout the Spanish territory.

Finally, during the Republic she intensified her political commitment. From the time of the Proletarian Theatre - created in 1932 - she enrolled in the Communist Party of Spain (PCE), in which environment the Proletarian Theatre unfolded. But her political commitment did not end there. Some time later, according to her daughter Carlota Leret, O'Neill left the communist militancy in 1935 and joined the Izquierda Republicana [Republican Left] party, led by Manuel Azaña, who was President of the Spanish Republic. This would mean that when arrested in 1936, she was no longer affiliated with the PCE but with Izquierda Republicana. Hence, during her incarceration, Carlota did not at any time act as part of the communist militancy.

These - and many other personal traits which would be too numerous to elaborate here - make Carlota a 'modern woman' as far as Mangini (2001) understands the term. Rejecting the role of 'domestic angel', she plunged herself as a 'new woman' into the male world of work, knowledge and culture, hitherto closed to women. Through her political and social commitment, O'Neill perfectly embodied the role models, both as a woman and citizen, which were fostered by the Republic (Torres, 2003: 12).

To a certain extent, O'Neill had taken a few steps 'downwards' on the social ladder, and there were no longer any appearances or social status to keep up and protect. She had consciously reached out to the working classes: the proletariat. More specifically, the proletariat woman, as she announced in her magazine Nosotras and in her play Al Rojo, where prostitution was also inextricably bound up with working-class women. It is therefore clear that Carlota, like many other modern women, expressed from early on a firm interest in 'women's issues' and 'feminist problems' (Mangini, 2001: 93). In contrast, at the time, these 
issues were not a priority for the communists: first, they needed to bring about a proletarian revolution, and once equality for all people was attained, women's problems would also be solved.

In short, Carlota O'Neill moved downwards on the social ladder for economic reasons, for her early assumption of the ideas of free love and also her closeness to the world of the proletariat and the proletarian women in particular, and even more specifically, to prostitutes. Her social awareness and political commitment deepened and she put her talent as a writer and intellectual at the service of the cause. This helps to explain who she was as a sexual liberal as well as her sociopolitical commitment.

These are among the factors that explain Carlota's liberal attitude while she was imprisoned by Franco. She had no need to distance herself from non-political prisoners for reasons of sexual morality, unlike her average fellow prisoner (see the quotation from Carrillo given earlier). Additionally, unlike other communist prisoners who left us with their valuable and courageous accounts of their stays in Franco's prisons, she was not subject to any kind of political discipline, neither did she feel the need to demonstrate constant virtue.

\section{Final remarks}

The Spanish Civil War, which led to Franco's dictatorship, created a powerful repressive machinery which lasted for many years after the end of the war. Prisons were overcrowded with political and non-political prisoners, many of them prostitutes, the result of the prevailing misery. Franco's regime never granted these female political prisoners official standing, so one of their main concerns was to gain the recognition they thought they were entitled to.

The unwavering organization of political prisoners was to avoid being demoralized in the face of harsh oppression and long sentences. The prison staff did everything possible to counteract this organization by means of promoting confrontation between non-political prisoners and political prisoners. The latter used their sexuality as an insurmountable barrier to mark their social distance toward the former.

The prostitutes, as well as other non-political prisoners, indulged in transgressive forms of sexuality, such as autoeroticism and lesbianism, which were unacceptable to the communist militant mindset of the political prisoners. They completely denied sexual desire, not just that of other people, but their own as well. In the usual bigoted mindset of the era, shared by female activists, such relationships were ascribed a meaning that was contrary to the exemplary behaviour that the political prisoners wanted to convey. Furthermore, the prison staff could use these transgressions for their own purposes, which would render vulnerable the prisoners who engaged in such acts.

To survive discipline was necessary. That much was clear to the political prisoners. They were determined not to be crushed by the prison authorities so that they decided to counteract all attempts by the authorities to break them. In order 
to maintain discipline, they had to strengthen their organization - they were women of the party - and friendship networks - called communes or families, organizational cells, which were essential for survival. This form of organization supported the political prisoners through every lack that they suffered while imprisoned. The prospect of 30 years in prison under harsh conditions of confinement was sufficient to dampen the spirit of even the most optimistic person. The prostitutes, by contrast, served sentences of no more than a few months. The political prisoners had to be as strong in body as in mind. The prison atmosphere was very harsh.

The political prisoners even used arguments about the social degeneration of lesbians in this struggle. Paradoxically, Franco's dictatorship put forward similar arguments about racial degeneration regarding the rojos: the hope was to make them inferior and, thus, find a justification for their persecution. Therefore, many of the uneducated prostitutes were shocked at the thought of being in close proximity with the rojas whores.

Carlota O'Neill, one of Franco's Republican prisoners from the very onset of the Civil War, lived through this situation. She had a bohemian and cultural background. Her excellent and powerful book Una Mujer en la Guerra de España [A Woman in the Spanish War] shed light on the harsh and difficult realities of this very dark period in recent Spanish history. We can also learn about O'Neill herself, a woman who was 'a hundred years ahead of her time', as her daughter Carlota Leret O'Neill states. She was a precocious, talented writer, a committed cultural, political and social intellectual; she supported avant-garde causes, such as free love, abortion rights and prostitution as well as other topics she came across during the ups and downs of her life (for instance lesbianism).

This meant she held a unique position in her time, as a liberal on matters having to do with sexuality: descriptions of heterosexual desire among imprisoned women; descriptions of lesbian relationships among young prisoners and of the censorship of other captives towards them, and of allegations of sexual violence suffered by the prisoners, all punctuate her writing - a high-quality literature piece by the way.

After the change in the prostitutes' attitudes towards political prisoners, upon whom they had looked down as degenerates, O'Neill would lend her voice to the heterogeneous women involved in prostitution in the miserable and repressive environment of the 1930s and 1940s in Spain. Her interest and empathy were such that unintentionally, she eventually became an authority on the subject, as evidenced by contemporary historians of prostitution from that period.

In brief, these texts by communist prisoners shed light on a new episode marking the division between decent women and prostitutes, between 'good girls' and 'bad girls', between political prisoners and non-political prisoners in Franco's prisons divisions from which the writer and political prisoner Carlota O'Neill distanced herself. We have selected issues such as class and education as a way of explaining the divide between tradition and modernity, in connection with the different points of view on women's sexuality in prison, during the Civil War and post war periods, in Franco's Spain. 


\section{Acknowledgements}

This work was conducted as part of the research project entitled 'Los cambios de las políticas públicas en torno a la sexualidad femenina desde el franquismo a la democracia: de la represión a las políticas públicas de igualdad' [Changes in public policy regarding women's sexuality from Franco to democracy: the repression of the public policies of equality], file number 140/07, approved under the National I+D+I Plan (2004-2007). Scientific Research and Technological Development Projects. PROGRAMME: Strategic Action on the Promotion of Equal Opportunities between women and men.

\section{Notes}

1. The documents obtained from this source will hereinafter be referred to as 'Courtesy of CLO'.

2. Hernández Holgado, email dated 8 March 2009.

3. Old fashioned term for 'homosexuality'.

4. 'Had their way' is a euphemism for raping.

5. Courtesy of CLO.

\section{References}

Arnalte A (2003) Redada de Violetas. La Represión de los Homosexuales durante el Franquismo. Madrid: La esfera de los libros.

Barba D (2009) 100 Españoles y el Sexo. Barcelona: Plaza\&Janés.

Cárceles españolas (1948) Oficina Informativa Española.

Comission Internationale contre le Régime Concentrationnaire (1953) Livre Blanc sur le Sistème Pénitentiaire Espagnol. Paris: Le Pavois.

Cuevas Gutiérrez T (2004 [1985]) In: Montes Salguero JJ (ed.) Testimonios de Mujeres en las Cárceles Franquistas. Huesca: Instituto de Estudios Altoaragoneses.

Cuevas V (1953) Regeneración del Preso. Madrid: Temas Españoles.

Doña J (1978) Desde la Noche y la Niebla: Mujeres en las Cárceles Franquistas: NovelaTestimonio. Madrid: Ediciones La Torre.

Echols A (1989) Daring to Be Bad. Radical Feminism in America 1967-1975. Minneapolis: University of Minnesota Press.

Falcón L (1989 [1979]) Los Hijos de los Vencidos. Barcelona and Madrid: Vindicación Feminista.

García C (1982) Las Cárceles de Soledad Real 20: Una Vida. Madrid: Alfaguara.

Guereña JL (2003) La Prostitución en la España Contemporánea. Madrid: Marcial Pons Historia.

Hernández Holgado F (2003) Mujeres Encarceladas. La Prisión de Ventas: de la República al Franquismo, 1931-1941. Madrid: Marcial Pons.

Mangini S (2001) Las Modernas de Madrid. Las Grandes Intelectuales Españolas de la Vanguardia. Barcelona: Península.

Moga V (2004) Las Heridas de la Historia: Testimonios de la Guerra Civil Española en Melilla. Barcelona: Edicions Bellaterra.

Nicolás Marín ME and López García B (1986) La Situación de la Mujer a través de los Movimientos de Apostolado Seglar: La Contribución a la Legitimación del Franquismo (1939-1956). In: Durán MA and Capel RM (eds) Mujer y Sociedad en España (17001975 ) Madrid: Ministerio de Trabajo y Asuntos Sociales, Instituto de la Mujer, 365-390. 
Núñez M (2003) Mujeres Caídas. Madrid: Oberón.

Olmeda F (2004) El Látigo y la Pluma. Homosexuales en la España de Franco. Madrid: Oberón. O’Neill C (1931) Nosotras, Revista Femenina Año 1, número 1, 10 de noviembre.

O'Neill C (1933) Al Rojo. Unpublished theatre play.

O’Neill C (1960) Qué Sabe Usted de Safo. México DF: Libro Mex Editores.

O’Neill C (1964) Una Mexicana en la Guerra de España. México DF: Libro Mex Editores.

O'Neill C (1978) Trapped in Spain. Toronto: Solidarity Books.

O’Neill C (2006 [2003]) Una Mujer en la Guerra de España. Madrid: Oberón.

Osborne R (2002 [1993]) La Construcción Sexual de la Realidad. Madrid: Cátedra.

Osborne R (2009) La Sexualidad como Frontera: Militancia, Supervivencia y Negación del Lesbianismo por parte de las Presas Políticas de los Nazis y el Franquismo. Política y Sociedad 46(1-2): 57-77. (URL (accessed 12 July 2011): http://revistas.ucm.es/index.php/ POSO/article/view/POSO0909130057A/21844.

Osborne R (2010) 'Entonces ellas se convertían en rojas': Desencuentros y Amistades entre Prostitutas y Rojas en las Cárceles Franquistas? Mora, Revista del Instituto Interdisciplinario de Estudios de Género, Facultad de Filosofía y Letras de la Universidad de Buenos Aires 15(2). URL (accessed 5 July 2011): http://www.scielo.org.ar/scielo.php?pid=S1853-001X2009000200004\&script=sci_arttext.

Pheterson G (1996) The Prostitution Prism. Amsterdam: Amsterdam University Press.

Roura A (2005) Un Inmenso Prostíbulo. Mujer y Moralidad en el Franquismo. Barcelona: Editorial Base.

Sánchez P (2009) Individuas de Dudosa Moral. La Represión de las Mujeres en Andalucía (1936-1958). Barcelona: Crítica.

Snitow A, Stansell C and Thompson S (eds) (1983) Powers of Desire. (The Politics of Sexuality). New York: Monthly Review Press.

Torres R (2006 [2003]) Prólogo. In: Carlota O’Neill Una Mujer en la Guerra de España. Madrid: Oberón, 11-15.

Vallejo Nágera A and Martínez EM (2003 [1939]) Psiquismo del Fanatismo Marxista. Investigaciones Psicológicas en Marxistas Femeninas Delincuentes. In: Vinyes R, Armengou M and Belis R (eds) (2003) Los Niños Perdidos del Franquismo. Barcelona: DEBOLSILLO, 256-271.

Vance C (ed.) (1984) Pleasure and Danger: Exploring Female Sexuality. London: Routledge \& Kegan Paul.

Vinyes R (2004) El Daño y la Memoria: las Prisiones de María Salvo. Barcelona: Plaza\&Janés.

Vinyes R, Armengou M and Belis R (2003) Los Niños Perdidos del Franquismo. Barcelona: DEBOLSILLO.

Walkowitz J (1983) Prostitution and Victorian Society. Cambridge: Cambridge University Press.

Raquel Osborne is Professor of Sociology at the National University of Education at Distance (UNED) in Madrid. She has held a Fulbright Scholarship at New York University, where she got a $\mathrm{MPh}$. Her main lines of research are related to contemporary issues and debates related to the intersection of Sexuality and Gender. Violence against women and positive action also attract her attention. Her present research interests concern female sexuality under Franco's regime. 